\title{
Aflorando sentidos: discurso político e doses de poesia
}

\section{Maria Stela Torres Barros Lameiras}

Doutora em Lingūística pelo Programa de Pós-

graduaçāo em Letras e Lingüística da

Universidade Federal de Alagoas (Ufal), professora e vice-diretora da Faculdade de Letras

(Fale), Ufal. Professora de Francês e de

Lingüística Aplicada, na Universidade Federal de

Alagoas.

Resumo: Nosso objetivo neste artigo é de fazer ver a estrutura a partir do ponto de vista de Pêcheux, que vê o "abalo da estrutura" face ao acontecimento e o seu entorno. Seguindo os fundamentos da Análise do Discurso (AD), tentase perceber 0 transporte do fato, de seu nascedouro até às mídias, no qual são percebidos os efeitos de sentido desse percurso. Considera-se, ainda, a inegável relação entre Sujeito, Língua e História, uma relação entremeada pela memória.

Palavras-chave: acontecimento; discurso; mídias; efeitos de sentido
Résumé: Notre objectif dans cet article c'est de faire voir la structure à partir du point de vue de Pêcheux, quil la voit "sécouée" par l'événement et ses alentours. À l'aide des fondements de l'Analyse du Discours (AD), on essaie de voir le parcours du fait lui-même jusqu'aux médias, oùl' on voit les effets de sens de ce transport. Dans ce contexte, il faut considérer l'indéniable relation entre Sujet, Langue et Histoire, une relation qui ne peut/ne doit pas négliger la mémoire et l'histoire.

Mots-clés: événement; discours; médias; effets de sens 

Quem olha para fora sonha; quem olha para dentro desperta. Carl Jung

Sem esperança não surge o inesperado. Murilo Mendes

Neste artigo, fazemos uma breve revisão de alguns conceitos e dos caminhos mais recentes da Análise do Discurso (doravante $A D$ ), seguindo as perspectivas dos estudos na França e no Brasil.

Com base nessas perspectivas, lançamos um olhar para um corpus, dividido em duas partes, compostas de três textos cada, dando-se sua leitura/análise em pares (apesar de eles serem "ímpares" em sua enunciação). Na primeira parte, trazemos três trechos da fala do presidente Lula, em momentos distintos, embora todos relacionados com o poder da presidência. Os dois primeiros estão relacionados com a condição de Lula, presidente eleito, sendo um extraído de seu discurso de posse no Congresso Nacional, em 1ㅇ de janeiro de 2003,

Cada um de nós, brasileiros, sabe que o que fizemos até hoje não foi pouco, mas sabe também que podemos fazer muito mais. Quando olho a minha própria vida de retirante nordestino, de menino que vendia amendoim e laranja no cais de Santos, que se tornou torneiro mecânico e líder sindical, que um dia fundou o Partido dos Trabalhadores e acreditou no que estava fazendo, que agora assume o posto de supremo mandatário da nação, vejo e sei, com toda clareza e com toda a convicção, que nós podemos muito mais. [...] hoje é o dia do reencontro do Brasil consigo mesmo. Agradeço a Deus por chegar até onde cheguei. Sou agora o servidor público número 1 do meu país. (T1) 1
1 O corpus da análise deste artigo será representado ao longo do texto pela identificação, na forma a seguir: T1, T2, T3, T4, T5, T6. 
enquanto o segundo é um pequeno trecho extraído de seu pronunciamento em 29/10/2006, na Avenida Paulista, logo após a confirmação da vitória que lhe conferira a reeleição:

É uma vitória que me deixa realizado como político. Foi a vitória dos de baixo contra os de cima. É o andar de baixo que chegou lá em cima. E pode ter certeza que jamais abdicarei do lado que eu sou.(T2)

O terceiro texto que compõe a primeira parte do corpus é uma fala do presidente Lula, então candidato à reeleição, em 26 de setembro de 2006, em plena campanha eleitoral, por ocasião de um comício em Belo Horizonte:

2 "A posse", de Haroldo de Campos, in: Folha de S.Paulo, 19 de janeiro de 2003. Caderno Mais.

O Lula é uma parte do povo deste país que adquiriu consciência política. É por isso que eu não caio. Porque eu não sou sozinho. A hora que eles tirarem as minhas pernas, eu vou andar pelas pernas de vocês; a hora que eles tirarem os meus braços, eu vou gesticular pelos braços de vocês; a hora que eles tirarem o meu coração, eu vou amar pelo coração de vocês. E a hora que eles tirarem a minha cabeça, eu vou pensar pela cabeça de vocês.(T3)

A segunda parte do corpus é composta de três textos de expressão poética, um deles evocado em uma matéria jornalística de Elio Gaspari. São eles um poema de Haroldo de Campos² (2003), publicado após a posse de Lula, em janeiro de 2003,
A Posse (T4)
de repente
no país do
bacharel de Cananéia
dos bacharéis de canudo e
anel no dedo e dos 


doutores de borla e capelo
no país dos
coronéis
latifundiários de baraço
e cutelo (melhor
dizendo de serrote elétrico
corta-homens)
de nobres na curul e
pobres no curral
um
metalúrgico (sem
anel de grau sem
toga doutoral sem
sabença de papel passado) um
torneiro mecânico
formado na
universidade da vida
(severina) assoma
no altiplano de
brasília e toma
posse
da República numa
apoteose de povo
dando novo sentido à palavra
pátria.

e o poema "cordelista" de Patativa do Assaré, evocado por Elio Gaspari, como dissemos anteriormente, em matéria publicada em diversos jornais brasileiros (Folha de S.Paulo, Correio do Povoetc.), no dia 1o de novembro de 2006. Elio Gaspari diz que "nosso guia [Lula] deu voz à alma de Patativa do Assaré, o grande poeta morto em 2002, aos 92 anos, com mais de dez secas nas costas e mil poemas na cabeça". Segundo a matéria em foco, Patativa do Assaré, esse grande poeta cearense, era eleitor de Lula, embora achasse que "o medo do povo" não levaria Lula à presidência. A seguir, o poema de Patativa do Assaré: 
Tudo o que procuro acho.

Eu pude vê neste crima.

Que tem o Brasi de Baxo

E tem o Brasi de Cima.

Brasi de Baxo, coitado!

É um pobre abandonado;

O de Cima tem cartaz,

Um do ôtro é bem deferente:

Brasi de Cima é pra frente.

Brasi de Baxo é pra trás.

[...]

Inquanto o Brasi de Cima

Fala de transformação,

Indústria, matéra prima,

Descobertas e invenção,

No Brasi de Baxo isiste

O drama penoso e triste

Da negra necissidade;

É uma coisa sem jeito

E o povo não tem dereito

nem de dizê a verdade.

[...]

Meu Brasi de Baxo, amigo,

Pra onde é que você vai?

Nesta vida de mendigo

Que não tem mãe nem tem pai?

Não se afrija nem se afobe,

O que com o tempo sobe,

O tempo mesmo derruba;

Tarvez ainda aconteça

Que o Brasil de Cima desça.

E o Brasi de Baxo suba.

[...]

Mas, tudo na vida passa,

Antes que a grande desgraça

Deste povo que padece, 
Se istenda, cresça e redobre,

O Brasi de Baxo sobe

E o Brasi de Cima desce.

[...]

Vai ser legá e comum.

Em vez deste grande apuro,

Todos vão ter no futuro,

Um Brasi de cada um.

Por último, trazemos um trecho de um poema de Rainer Maria Rilke:

Que farás tu, meu Deus, se eu perecer? (T6) ${ }^{3}$

Que farás tu, meu Deus, se eu perecer?

Eu sou o teu vaso - e se me quebro?

Eu sou tua água - e se apodreço?

Sou tua roupa e teu trabalho

Comigo perdes tu o teu sentido. [...]

Em ambas as partes do corpus, buscamos fazer um percurso, tentando atravessar redes de memória, nas quais a interdiscursividade se faz presente, em sua percepção mais corrente da atualidade, influenciada por diversas tradições científicas, que é o interdiscurso como "um conjunto de discursos outros percebidos pelo discurso objeto do analista" (PAVEAU; ROSIER, 2006). ${ }^{4}$

Nessa linha de reflexão, os discursos-transversos representam o caminho da tríplice articulação na obra de Pêcheux (MALDIDIER, 1990, p.235-236): "o do apelo ao intradiscurso (como nós dissemos), a do 'retorno do Universal' no sujeito (como se sabe) e a da 'universalidade implícita em toda situação humana' (como cada um pode ver)". Para continuar essa reflexão, deveríamos, como o fez Maldidier (op. cit.), olhar o sujeito "assujeitado" diante do universal, da mesma forma que singularmente insubstituível. Deveríamos, talvez, falar aqui também da interpelação ideológica dos indivíduos em sujeitos

${ }^{3}$ Rainer Maria Rilke (1875-1926), Que farás tu, meu Deus, se eu perecer?, Tradução de Paulo Plínio Abreu.

${ }^{4}$ Marie-Anne PAVEAU, da U. Paris 13-EA 3119 Céditec

Paris 12. Laurence ROSIER, da Université Libre de Bruxelles, groupe international Ci-dit. «Éléments pour une histoire de l'analyse du discours. Théories en conflit et ciment phraséologique". Colloque francoallemand: «L'analyse du discours en France et en Allemagne: Tendances actuelles en sciences du langage et sciences sociales». Disponível em :: http:// www.johannesangermueller.de/ deutsch/ADFA/ paveaurosier.pdf. Acesso em: 13 jul 2006. 
(ALTHUSSER, 1974), esse espaço de subjetividade, que nós optamos por tratar como um "desdobramento do sujeito" no movimento incessante de identificação "da exterioridade com a própria interioridade do sujeito", no dizer de Pêcheux (MALDIDIER, 1990, p.237). Essa discussão sobre sujeito é, por si só, uma questão que merece um tratamento mais profundo, sem o devido espaço neste estudo. Não podemos, entretanto, deixar de registrar a nossa concepção de sujeito:

As inquietações e as encruzilhadas epistemológicas em torno do sujeito estão longe de uma solução. É inegável, porém, que não há mais como "divinizálo", ter o sujeito inteiramente autônomo de sua prática discursiva. Vê-lo divinizado dessa forma, "dono" de seu dizer é compará-lo a um regente de uma orquestra sem músicos (toda orquestra emite sons a partir dos movimentos da "batuta" de seu regente, mas todo regente, para obter uma sinfonia, precisa dos sons emitidos pelos músicos que ele rege); não há tampouco como "dissolver" esse sujeito face ao discurso. Imprescindível mesmo é reconhecer o espaço que o sujeito ocupa no discurso, considerando as condições de produção, que condicionam, corroboram, limitam e ampliam o poder de ocupação desse espaço. (LAMEIRAS, 2006, p.155)

Muitos estudos têm sido apresentados com os fundamentos teórico-metodológicos da $\mathrm{AD}$, dita de tendências francesas. Entretanto, cada um deles traz olhares diferentes, de sujeitos diferentes, sobre o mesmo corpus e sobre corpus diferentes. Isso me faz evocar um pequeno conto, que ilustra bem essa diversidade de olhares. Dizem que, certa vez, o grande compositor Mozart, ao ser perguntado como compunha as suas músicas, afirmou que usava as mesmas notas que os outros compositores, os espaços é que eram diferentes. 
Ouso aproximar essa imagem dos trabalhos de pesquisa que não ocupam o mesmo espaço, fundamentados em tendências teóricas nem sempre em sintonia epistemológica, como é o caso da AD: a ocupação dos espaços não se dá na mesma medida; o tempo, o lugar, o objeto, as circunstâncias e os sujeitos da enunciação movimentam-se em "ondas de fundo discursivo" (BONNAFOUS; TOURNIER, 1995), que se pluralizam em uma vastidão oceânica. Os conceitos da $\mathrm{AD}$ sobre formações discursivas e ideológicas, os discursos transversos que atravessam e fazem conexões entre os elementos do discurso, as tensões em torno do sujeito que se desloca, ou que busca se situar, imprimindo seu espaço; enfim, todas essas noções têm provocado e atraído o mundo acadêmico, ao mesmo tempo em que surgem trabalhos de inspirações e fundamentações distintas.

Vê-se, com maior freqüência, uma abertura de fronteiras para o objeto de análise; seria melhor dizer que, em vez de uma abertura de fronteiras, se vivem 0 reconhecimento e a convivência de horizontes diferentes. Não devemos, nem podemos deixar que o rigor das filiações teóricas represente fronteiras intransponíveis, impedindo a visão da amplitude dos horizontes. Seria, acreditamos, uma atitude de um purismo, até certo ponto ingênuo, que iria de encontro ao curso da história, se, em nome da cientificidade, abríssemos mão da vida de uma materialidade lingüística, a cada novo espaço e a cada novo tempo em que se processam os sentidos. Esse movimento de sentidos evidencia a sua mobilidade face ao tempo, face ao espaço, face à história, face ao sujeito; não há, portanto, como apagar as condições de produção de um discurso.

Abordando a AD do ponto de vista de uma política de leitura, Courtine (2006, p.9) diz o seguinte:

O aparecimento da problemática do discurso no interior da lingüística francesa é contemporâneo à conjuntura política dos anos 1968-1970, dominada
${ }^{5}$ Retomamos uma expressão da qual fazemos uso em nossa tese de Doutorado (LAMEIRAS, Entre os contos de uma Posse e o Poder da Palavra: "ligações perigosas" entre a mídia, a palavra e o poder político, 2006). 
${ }^{6}$ Esta expressão, na sua origem, "physicalité", foi utilizada por Gary Hill, artista americano, em entrevista publicada no jornal francês Libération, 3, 4 de janeiro de 2007, para se referir à profundidade da superfície textual, mostrando que a leitura de um texto "difícil" reside no fato de que não se está inteiramente seguro de seu sentido. A utilização que fazemos, por empréstimo, dessa palavra não está associada ao grau de dificuldade do texto, mas, sim, às condições de produção de um texto, das quais "jorram" sentidos. pelos acontecimentos de maio de 68 . $O$ discurso flutuava perdido no espaço.

É inegável que a pulsão social e política dos movimentos populares na França, em 1968, provocou muitas mudanças na vida política, social e cultural para além daquele país, inclusive com fortes reflexos no Brasil. E o discurso que "flutuava perdido no espaço", como afirma Courtine (op. cit.), foi ganhando espaços de análise, de leituras diferenciadas.

Por muito tempo - e isso ainda perdura - a palavra discurso tinha um reducionismo de sentido que a associava a uma fala específica para um determinado momento cívico, festivo: um discurso político, um discurso alusivo a uma comemoração. Enfim, discurso era um texto, aparentemente com objetivo definido, por vezes "recheado" de estruturas lingüísticas ambíguas na manifestação de sentidos genéricos, estrategicamente postas na pretensa estabilidade da estrutura e pronunciadas, quase sempre, em tom solene. Fazer um discurso era sinônimo de poder, de quem estava autorizado a fazer uso da fala, ou mesmo falar em nome de outros não eram, entretanto, as vozes da plurivocidade, cujas filigranas exibem um entrelaçamento de sentidos, para além da horizontalidade da materialidade discursiva.

Fazendo essa travessia no tempo e no espaço do discurso, perguntamo-nos: mudou a "fisicalidade" 6 do discurso, ou mudaram as teorias que lhe lançam um olhar?

Nesse espaço de interpretação, percebe-se o significativo papel da mídia, no percurso entre a captação do fato e o seu transporte para o órgão de imprensa. De Chanay (2006), em artigo no qual reflete sobre a obra de Patrick Charaudeau, Le discours politique. Les masques du pouvoir ("O discurso político. As máscaras do poder"), vê a questão do discurso a partir da

"degenerescência do político" — da dissolução do debate de idéias em benefício da batalha das imagens; 
da elaboração refletida e negociada de projetos de vida coletiva, projetada a longo prazo, em benefício da produção de discursos de consumação imediata, voltados ao efêmero e à atualização da cota de popularidade dos atores políticos: enfim, da dissolução do político no midiático. (DE CHANAY, 2006, p. 4)

Neste artigo, buscamos entender, via materialidades discursivas, como se dão as relações entre os dizeres veiculados e os sentidos produzidos na sociedade de falantes. Essas relações são construídas pelas redes de memória dos sujeitos, interagindo inter e intradiscursivamente. São as práticas discursivas desses sujeitos que se inscrevem no curso da história; e as mídias, nesse curso da história, estão no centro das questões de interpretação do mundo, seja no registro dos chamados fait-divers da cotidianidade, seja nas matérias sobre os acontecimentos do dia-a-dia - que reverberam, também, na produção literária, como expressão de uma sociedade -, seja no registro das descobertas científicas que modificam o mundo.

É no entrecruzamento de sentidos entre língua (linguagem), história e redes de memória do sujeito que situamos esta análise. Tentamos entender as relações processadas na inquietude do movimento que põe a estrutura e o acontecimento em uma espécie de via de mão dupla, sob a perspectiva de Pêcheux (1990): a estrutura, como lugar estabilizado do acontecimento, e o acontecimento, como lugar de abalo da estrutura.

Olhando o "acontecimento", dentro da aparente estabilidade da estrutura, inquietam-me inúmeros questionamentos sobre a $A D$ e sobre os seus rumos na atualidade. O quadro da história da AD é atravessado por imprecisões, por posições teóricas, por vezes distintas, por vezes paralelas; por correntes que reivindicam o primado de um campo de um estudo amplo, ambicioso, para onde convergem (e divergem) as ciências da linguagem. 
Entretanto, quaisquer que sejam as posições teóricas que delineiam o quadro da história da $\mathrm{AD}$, elas trazem, inevitavelmente, as marcas das relações que se estabelecem entre ciência e sociedade, através das materialidades discursivas, dos dizeres que circulam nos meios de comunicação, na sociedade em geral. Para Moirand (2004), o que interessa são as formas de inscrição desses dizeres, o que permite estabelecer laços entre o sentido lingüístico e o sentido social, favorecidos pelo discurso. Ao fazer essa afirmação, a autora citada traz ainda o fundamento bakhtiniano que diz não haver palavras neutras para um membro de uma coletividade de falantes, mas, sim, palavras "habitadas" por vozes outras.

É essa plurivocidade que me faz gostar (sem pretender reduzir o sentido do "gosto científico"), ainda que esse gostar seja um tanto paradoxal em seus sentidos, da expressão de de Certeau, "floresta de narrativas jornalísticas, publicitárias, televisivas" (1990, p. 271), para falar das mais diferentes formas de comunicação das mídias. Ao empregá-la, o autor citado refere-se ao ouvinte das informações diárias, que saturam uma sociedade, a tal ponto que chegam a articular nossas existências, guiandonos, de certa forma, em meio à "cobertura" dos acontecimentos. Uma "cobertura" que descobre sentidos encobre outros e faz brotar sentidos novos, expondo-os todos a uma arena de conflitos sociolinguageiros.

A AD permanece "fiel" ao texto, ao corpus selecionado que é a base do analista do discurso. Essa base só ganha corpo, porém, quando a materialidade lingüística é vista através de um processo intermitente que começa nas condições de produção do discurso e que percorre os fios que tecem os sentidos nos caminhos que separam ou unem autores e leitores. Trata-se do texto em relação ao discurso, às formações discursivas. Para a AD, as formações discursivas são comumente vistas como componentes ou imbricadas de uma determinada formação ideológica, em articulação com as condições de produção em que se realiza o discurso. 
Em nossa tese de doutorado (cf. nota de rodapé 5), trazemos Guillaumou (2005) em um momento de intenso questionamento sobre a noção de FD; ele se mostra inclinado, em um determinado momento de suas interrogações epistemológicas, a considerar as formações discursivas fora da dianteira da cena discursiva, de forma definitiva. Entretanto, mesmo que assim o fizesse, diz Guillaumou (op. cit.), haveria sempre aquele espaço vazio, que seria preenchido por "alguma coisa que existe" e "alguém que fala". Nesse ponto, o autor trata da existência do sujeito empírico em determinada situação social.

Sabe-se que, em qualquer caminho que se pretenda trilhar na vida, seja ele pessoal ou profissional, a etapa seguinte só é "determinada" na medida em que o percurso vai sendo feito. Associando essa idéia aos caminhos trilhados pela AD, citamos Mazière (2005, p. 112-113), para quem a $\mathrm{AD}$ se constitui em

uma matriz de invenções, de hipóteses e de experimentações dentro da lingüística e continua a incomodar a disciplina, apresentando uma resistência a certas indiferenças em relação à língua que se desenvolvem hoje em dia nas ciências humanas e sociais.

Tenta-se, pois, com base nesse ponto de vista, preservar o espaço da lingüística para a $\mathrm{AD}$, sem, entretanto, lhe negar o espaço vital da história, nesse contexto em que ocorre a relação entre sujeito, língua e história.

Situamo-nos na eleição do ano de 2006, quando do segundo mandato conferido ao presidente Lula (esperando que a "contigüidade" desse acontecimento não represente a "continuidade" de tantos acontecimentos que não deveriam ter ocorrido), para ressaltar uma espécie de dicotomia que se tem "aprofundado" (no seu sentido mais literal) entre um dito "andar em cima" e um dito "andar de baixo", aquele, visto como a elite, e o outro, visto como o povo. 
O presidente Lula, ao festejar sua reeleição, no domingo 29 de outubro, afirmou: "Foi a vitória dos de baixo contra os de cima. É o andar de baixo que chegou lá em cima" (T2). Essa visão dicotômica, de um fosso que não deixa de existir, desde sempre, tem sido retomada insistentemente, seja no discurso de Lula então candidato a presidente, seja no discurso de Lula, já na condição de representante do poder da presidência do país.

O sentido "genérico" da materialidade discursiva do (T2) apresenta algumas peculiaridades. Ao dizer, em uma forma verbal interlocutiva, dirigindo-se aparentemente a cada brasileiro em particular ("e pode ter certeza que jamais abdicarei do lado que sou"), o presidente Lula coloca uma força substancial, na expressão verbal, de valor nominal "sou", que não vem seguida de um predicativo. Nesse momento, parece haver uma espécie de cruzamento de sentidos com o verbo "estar", uma vez que existe uma relação de lugar - "do lado que eu sou" (T2). O efeito difuso dos sentidos, inclusive com a forma "jamais abdicarei", uma expressão que produz sentidos próximos de uma ação heróica (voltamos no tempo e na memória para ouvir ecoar expressão do gênero - "diga ao povo que fico"), ao mesmo tempo em que essa expressão é reveladora de poder, contribui para um esvaziamento do discurso, do qual fala Courtine (2006), ao se referir ao Partido Comunista.

A fala de Lula aparece aí como a reprodução do " poema de Patativa do Assaré (T5). O "Brasi de Baxo" é "coitado", é "abandonado", vive "o drama penoso e triste / da negra necissidade [...]". Mas o presidente Lula ascende mais uma vez ao poder da presidência da República, e ele reproduz o dizer do poeta, que é também seu e de parte significativa do povo brasileiro: "o andar de baixo chegou lá em cima".

A grafia do andar de baixo de Lula é diferente da grafia do poeta, mas não há distância no sentido de uma e de outra; os efeitos de sentido são similares. O "andar de baixo" (ou o "Brasi de baxo") fez o "Brasi de 
cima" descer. E, se as palavras do poeta cearense tivessem o poder de uma profecia, seria mais um passo para o povo brasileiro sair do apuro: "Todos vão ter no futuro, um Brasi de cada um” (T5). Há, porém, outro trecho do poeta que inquieta, e que nos faz refletir sobre a substância singular do papel que exercemos, no lugar que ocupamos: "o que com o tempo sobe, o tempo mesmo derruba".

Ao trazer o poema de Patativa do Assaré (T5), o jornalista Elio Gaspari fala ainda do descrédito que o poeta tinha de ver Lula chegar ao poder porque, segundo o poeta, diz o jornalista: “o povo tem medo". Essa expressão, dita, certamente, nas eleições anteriores em que Lula havia tentado chegar à presidência, pelo voto popular, atravessa o fio da história brasileira, nas últimas quase quatro décadas.

Em 2002, quando da campanha eleitoral para o segundo turno, no qual Lula e José Serra disputavam a presidência da República, a atriz Regina Duarte protagonizou um "acontecimento discursivo"7 que deu margem a muitas querelas político-semânticas. Ao tornar pública a sua opção pela candidato José Serra, a atriz argumentou: "estou com medo". Ela falava de um medo do desconhecido, de um medo da perda de estabilidade, um medo cujos efeitos de sentido não eram os mesmos da atriz Paloma Duarte, muito embora houvesse quem se "solidarizasse" com o mesmo medo de Regina Duarte, a exemplo da atriz Beatriz Segal. Entre tantas outras manifestações a respeito do medo, fosse de um ou de outro, o presidente Lula entra nesse jogo de efeito de sentidos, que crescia na mídia, para dizer, em um comício (2002), que o medo de Regina Duarte era, na verdade, medo das atrizes mais jovens.

Passadas as eleições de 2002, Lula, vitorioso, faz uso de uma expressão que se propagou, adquirindo ares de mantra político: "a esperança venceu o medo". Essa expressão, retomada com muita freqüência, aproxima-se do que Courtine (2006) considera como um esgotamento
${ }^{7}$ Sobre o enunciado de Regina Duarte e seus reflexos, em um processo de interlocução, destacamos o artigo de Ercília Ana Cazarin: A Leitura: uma prática discursiva, publicado na revista Linguagem em (Dis) curso, volume 6, número 2, maio/ago., 2006. 
lexical, um esvaziamento de sentidos, do qual falamos anteriormente:

As palavras, de repente, soam tão vazias que nos surpreendemos com o crédito de que elas puderam usufruir durante tanto tempo, nos surpreendemos ainda que elas tenham podido conquistar a adesão ou, ao contrário, suscitar tantos debates críticos. Repentinamente despojadas de seu valor performativo de fala eficaz, diríamos que a significação dessas palavras se desagrega e que sua referência se dissolve. (COURTINE, op. cit., p.113)

Voltamos ainda ao ano de 2003, no momento em que Lula assume a presidência da República, pela primeira vez. Em sua fala no Congresso Nacional, Lula já falava daquele "Brasi de baxo", "das necissidade" (T5), o Brasil do poeta e do povo brasileiro. No discurso do presidente Lula, ele se sentia - e o era, na verdade, de fato e de direito, autorizado a falar do lugar desse povo, cujas histórias, como a sua também, são "cheias" de capítulos que ressaltam as "necissidade" de uma população sofrida. É por isso que o presidente eleito podia fazer uso do pronome "nós", representando ali, "no altiplano de Brasília" (T4), a história de um brasileiro que lutou, sofreu, sonhou, acreditou e venceu. Com esse "nós inclusivo" (AuthierRevuz 1, 1995, p.207), o presidente conta a sua história de retirante nordestino, falando aí de um lugar no qual ele sabe haver uma identificação com o Brasil:

Cada um de nós brasileiros sabe que o que fizemos até hoje não foi pouco, mas sabe também que podemos fazer muito mais. Quando olho a minha própria vida de retirante nordestino, de menino que vendia amendoim e laranja no cais de Santos, que se tornou torneiro mecânico e líder sindical, que um dia fundou o Partido dos Trabalhadores e acreditou no que estava fazendo, que agora assume o posto de 
supremo mandatário da nação, vejo e sei, com toda clareza e com toda a convicção, que nós podemos muito mais. (T1)

Essa história é também a história de tantos outros personagens espalhados pelo Brasil; a materialidade discursiva apresenta uma vestimenta de uma seqüência de "orações", cuja relação de subordinação e coordenação, bem orquestrada sintática e semanticamente, atinge o seu "clímax". Esse clímax seria o momento que o presidente Lula considera como um ponto de encontro entre ele, como povo, e o Brasil: "[...] hoje é o dia do reencontro do Brasil consigo mesmo. Agradeço a Deus por chegar até onde cheguei. Sou agora o servidor público número 1 do meu país" (T1). Era o "Brasi de cada um" (T5), que parecia estar nascendo ali. Um Brasil dicotômico, que o poeta Haroldo de Campos também percebeu naquela "apoteose de povo / dando novo sentido à palavra pátria" (T4). $\mathrm{O}$ "Brasi de Baxo" (T5) deixara pra trás o "Brasi de cima" (T5), aquele país "dos bacharéis de canudo e / anel no dedo" (T4). A "Universidade da vida (severina)" tinha agora o seu representante "no altiplano de Brasília", diz o poeta o que o povo sabe, diz o poeta o que o povo sente:

\author{
um \\ metalúrgico (sem \\ anel de grau sem \\ toga doutoral sem \\ sabença de papel passado) um \\ torneiro mecânico \\ formado na \\ universidade da vida \\ (severina) (T4)
}

É essa "vida severina" que o poeta Haroldo de Campos traz de volta, em seu poema, e que representa uma identificação maior entre o presidente eleito e o povo. O apelo feito ao poema "Morte e vida severina", 
de João Cabral de Melo Neto, é uma prova inconteste dessa identificação:

\author{
[...] Somos muitos Severinos \\ iguais em tudo na vida: \\ na mesma cabeça grande \\ que a custo é que se equilibra, \\ no mesmo ventre crescido \\ sobre as mesmas pernas finas \\ e iguais também porque o sangue, \\ que usamos tem pouca tinta. [...]
}

Mais uma vez, o presidente Lula surge como representante dos "muitos Severinos iguais em tudo na vida": passados quase quatro anos, Lula era, mais uma vez, candidato à presidência da República, tentando então a reeleição. E ele volta a buscar, na fusão de homem de poder e homem do povo, a sua maior força política. Há um quê de apelo afetivo nessa fusão, quando o então candidato à presidência - e também presidente atual se faz ver como parte de um todo: "O Lula é uma parte do povo deste país que adquiriu consciência política" (T3).

Nesta mesma fala, Lula se referia a "eles":

O Lula é uma parte do povo deste país que adquiriu consciência política. É por isso que eu não caio. Porque eu não sou sozinho. A hora que eles tirarem as minhas pernas, eu vou andar pelas pernas de vocês; a hora que eles tirarem os meus braços, eu vou gesticular pelos braços de vocês; a hora que eles tirarem o meu coração, eu vou amar pelo coração de vocês. E a hora que eles tirarem a minha cabeça, eu vou pensar pela cabeça de vocês.(T3)

A que "eles", propriamente, Lula se referia? Seriam os habitantes do "Brasi de cima" (T5), que tentavam retornar ao poder? Aqueles do "país do / bacharel de Cananéia / dos bacharéis de canudo e / anel no dedo e 
dos / doutores de borla e capelo / no país dos / coronéis"? (T4). Fica difícil penetrar na "fisicalidade" desse pronome pessoal, com efeitos de sentido de pronome indefinido.

Essa indefinição é um efeito de sentido que percebemos no uso desse "eles" (T3) e caminha na mesma direção do que já chamamos de um esvaziamento de sentidos, seguindo Courtine (2006), quando ele se refere ao "esgotamento lexical" do discurso comunista. Esse "esgotamento" é possível também ser percebido na retomada da visão dicotômica que o discurso político no Brasil tem feito, ao trazer o contraponto do "andar de baixo" em relação ao "andar de cima".

A fala do presidente Lula, ilustrada neste artigo nos trechos identificados como T1, T2, T3, parece seguir a política do discurso "de fórmulas", no dizer de Courtine (2006, p.84):

Um discurso dialógico provocou os jogos de linguagem: o discurso político passa por uma profunda transformação na enunciação, tornandose um discurso curto, descontinuo e ininterrupto, ao mesmo tempo que o sujeito falante re-emerge enquanto a máquina política é apagada.

Mas se Courtine (op. cit.) fala de uma preocupação maior do discurso político da atualidade com o instante, em detrimento de sua inscrição na memória, sabe-se, também, que é impossível o seu apagamento na história: a inscrição na memória pode até não ser mais a prioridade do discurso político. Entretanto, o movimento das "ondas de fundo discursivo" fará sempre ressoar novos sentidos.

Esse espaço de sentidos que se pluralizam acontece no mesmo espaço no qual Pêcheux (1990, p.56) via a "agitação das filiações sócio-históricas de identificação", uma agitação que não deixará nunca de existir, pois haverá, sempre, na horizontabilidade da materialidade discursiva, a travessia de linhas verticais que a memória e a história não apagam, por mais que se construam cortinas na 
superfície material do discurso. Pelo contrário, a recuperação da história, na memória dos interdiscursos, abre cortinas e irrompe nos intradiscursos e deixa ver que as filiações sócio-históricas existem, mas não mais vistas sob a ótica de uma ortodoxia teórico-metodológica que é, paradoxalmente, uma herança de Pêcheux, e que amarra os dizeres em "um mesmo sistema de regras que funda a unidade de um conjunto de enunciados circunscritos sócio-historicamente" (MAINGUENEAU, 1996).

Este artigo não se lança à procura de passarelas improváveis entre o discurso político e doses de poesia. Acreditamos, sobretudo, na poesia como uma verdade profunda, interior, e é por isso, talvez, que sentimos a falta dela no discurso político da atualidade. Parece, então, um nonsense, colocar essa relação na dianteira de nosso estudo, quando selecionamos um corpus que estabelece laços de sentido entre trechos da fala do presidente Lula, como presidente e como candidato, e a expressão poética nas vozes de Haroldo de Campos, Patativa do Assaré e Rainer Maria Rilke.

Essa proximidade dos efeitos de sentido, das duas partes do corpus deste artigo, ultrapassa a horizontalidade da materialidade discursiva e transita nos interdiscursos da memória do povo brasileiro, ansioso, cada vez mais, por passarelas prováveis. Para a travessia dessas passarelas, é preciso resgatar/ construir a ligação entre o dizer e o fazer, dando vida à abstração das idéias. Ao atravessar essas passarelas, aí, sim, chegaríamos, um dia, à pátria do "novo sentido", de Haroldo de Campos (T4), ou ao "Brasi de cada um", de Patativa do Assaré (T5).

Esse elo entre o dizer e o fazer passa pela heterogeneidade discursiva, e pela heterogeneidade interlocutiva, nas quais há as maneiras de dizer de um e de outro, essa "representação da não-coincidência entre 'tuas palavras' e, 'as minhas'", seguindo Authier-Revuz (1, 1995, p.204). Não traremos aqui o sujeito / ou a "falta" do sujeito da psicanálise, nem também as questões da dialogia 
bakhtiniana, mas é inegável que os ecos dessas perspectivas também nutrem nossas inquietações.

Nas bordas dos dizeres, há de se levar em conta o tempo e o espaço dos discursos, da língua, dos sujeitos; e é nesse espaço de negociação dos sentidos que AuthierRevuz (1995 1 e 2) faz uma análise do discurso em sua relação interlocutiva, atravessada por outros discursos, uma relação entre as palavras e as coisas e entre as palavras com elas próprias.

Voltamos ao momento de Lula, candidato, em seu comício em Belo Horizonte, quando, ao se dirigir ao povo na terceira pessoa do singular, "O Lula é uma parte do povo..." (T3). Nesse momento, o presidente Lula deixa de ser, na sua fala, o homem do poder e provoca um efeito de sentido de fusão, na qual Lula se coloca como parte desse povo. Esse efeito de sentido parece entrar em "sintonia" com um poema de Rainer Maria Rilke. Nas duas falas ocorre uma espécie de efeito simbiótico; a fala do presidente adquire ares de "pastiche", nos versos: "Que farás tu, meu Deus, se eu perecer? / Eu sou o teu vaso - e se me quebro? / Eu sou tua água - e se apodreço? / Sou tua roupa e teu trabalho / Comigo perdes tu o teu sentido." (T6).

Não pretendemos — nem poderíamos fazê-lo situar Lula como o interlocutor da poesia de Rilke, que conversa com Deus e que revela a intenção de se perpetuar, "Que farás tu, meu Deus, se eu perecer?" (T6), cujo efeito de sentido aponta para uma unidade de sentido: "Comigo perdes tu o teu sentido" (T6). A fala de Lula parece revelar essa idéia de unidade de sentido entre ele e a presidência da República; é como se, sem Lula, a presidência da República perdesse o seu sentido de povo.

$\mathrm{Na}$ travessia que fizemos - e talvez apenas tenhamos tentado, do que pode parecer improvável fomos "à cata" dos sentidos que podem vir a aflorar de materialidades discursivas de gêneros distintos (discurso político e poesia), mas que são produzidas, ambas, em meio a um processo que põe em relação o sujeito, a língua 
${ }^{8}$ Inspiro-me aqui na expressão que dá nome à obra de Elias Canetti: Língua absolvida, Companhia das Letras, 1987. e a história, essa tríade que ocupará sempre, acreditamos, a dianteira dos estudos da AD.

\section{Considerações no meio de um caminho...}

só a pergunta pode apontar um caminho para a frente; a resposta é apenas a metade do caminho [...].

Jostein Gaarden

Ecos, ondas, movimentos - palavras que, associadas ao discurso, provocam desdobramentos; desdobramentos que poderão vir, a partir deste estudo, dando origem a outros sentidos, "coincidentes" ou não com os sentidos que eu construí.

Digo isso do lugar de quem aprendeu, com as circunstâncias, a importância da conjugação plural para, depois, essas circunstâncias fazerem entender que o plural só existe a partir do singular. Vejo-me distante das teorias canônicas que se fecham às perspectivas que vão surgindo, inevitavelmente, com a evolução do tempo e das idéias. Com esse posicionamento, não tenho a pretensão de condenar ou de "absolver"8 esta ou aquela corrente teórica. Trata-se, entretanto, da crença na plurivocidade, na construção a partir do contraditório; e é com esse espírito de incompletude que tento concluir este artigo.

Colocar um ponto final neste artigo traz a sensação de que esse é um ponto final cheio de interrogações e reticências. É um pouco como afirmou Érico Veríssimo, em seu livro O escritor diante do espelho: "Em geral quando termino um livro encontro-me numa confusão de sentimentos, um misto de alegria, alívio e vaga tristeza. Relendo a obra mais tarde, quase sempre penso 'Não era bem isto o que queria dizer"'.

E eu diria, ousando continuar essa reflexão, que eu quero mesmo - e bem sei que queremos todos nós, brasileiros ou não - é que a chama da esperança do povo possa permanecer viva, para além das práticas discursivas. E, ainda, que seja possível, sempre, "sonhar" com novos 
horizontes, e "despertar", a cada amanhecer, vivendo a "esperança do inesperado". A utopia do sonho pode vir a ser uma passarela provável... com doses de poesia, mas, sobretudo, com coincidências entre o dizer e o fazer.

\section{Notas:}

13) A leitura que fazemos a partir de trechos do discurso de Lula, como presidente e como candidato à presidência da República, não deve ser vista como uma questão prioritariamente política. Trata-se de uma curiosidade e de uma "inquietude" de analista do discurso - e de cidadã, que se sente, como o presidente Lula, "parte do povo deste país" (T3) e, conseqüentemente, também, como parte de sua história.

2a) A tradução de trechos citados a partir de obras em língua francesa são de responsabilidade da autora deste artigo. 


\section{Referências}

ALTHUSSER, Louis. Ideologia e aparelhos ideológicos do Estado. Lisboa: Presença/Martins Fontes, 1974.

AUTHIER-REVUZ, Jacqueline. Ces mots qui ne vont pas de soi : boucles réflexives et non-coïncidence du dire. Tome 1. Paris: Larousse, 1995.

AUTHIER-REVUZ, Jacqueline. Ces mots qui ne vont pas de soi. boucles réflexives et non-coïncidence du dire. Tome 2. Paris: Larousse, 1995.

BAKHTIN, Mikhail. Marxismo e filosofia da linguagem. 2.ed. Trad. de Michel Lahud e Yara Fratecshi Vieira. São Paulo: Hucitec, 1981.

BONNAFOUS, Simone; CHARAUDEAU, Patrick. Les Discours des Médias, In: Le français dans le monde. Vanves: Hachette, 1996, p. 39-45.

BONNAFOUS, Simone; TOURNIER, Maurice. Analyse du discours lexicométrie, communication e politique. In: MAINGUENEAU, Dominique (Org.). Revue Langages. n: 117. Les Analyses du Discours en France. Paris: Larousse, 1995, p.6781.

COURTINE, Jean-Jacques. Metamorfoses do discurso político: derivas da fala pública. Trad. de Nilton Milanez, Carlos Piovezani Filho. São Carlos: Claraluz, 2006.

DE CERTEAU, Michel. L'invention du quotidien. 1. arts de faire. Paris: Éditions Gallimard, 1990.

DE CHANAY, Hugues. Patrick Charaudeau. - Le discours politique. Les masques du pouvoir. Paris : Vuibert, 256 pages (23 $€)$. Corpus, Numéro 4 Les corpus politiques : objet, méthode et contenu - décembre 2005, CR Comptes rendus, mis en ligne le 5 septembre 2006, URL: <http://corpus.revues.org/ document.html?id=320\& format=print $>$ 
GUILHAUMOU, Jacques. Où va l'analyse de discours? Autour de la notion de formation discursive. In : Revista Eletrônica Marges Linguistiques, $\mathrm{n}^{\circ}: 9$, maio de 2005. Disponível em:< http://revue-texto.net/Inedits/Guilhaumou_AD.html s. Acesso em: 17 abr. 2006, p.1-23.

LAMEIRAS, Maria Stela Torres Barros. Tese de Doutorado. Entre os contos de uma posse e o poder da palavra: "ligações perigosas" entre a mídia, a palavra e o poder político, L733e, SiBi-Sistema de Bibliotecas-Ufal, 2006.

MAINGUENEAU, Dominique. Les termes clés de l'analyse du discours. Paris: Seuil, 1996.

MAINGUENEAU, Dominique. L'analyse du discours et ses frontières. In : Revue Marges Linguistiques, n๊: 9. Saint-Chamas: Editions M. L. M. S. éditeur, Mai 2005. Disponível em: <http:// www.margeslinguistiques.com.> Acesso em: 19 set 2005

MALDIDIER, Denise. L'inquiétude du discours : textes de Michel Pêcheux présentés. Paris: Editions des Cendres, 1990.

MAZIÈRE, Francine. L'analyse du discours. Que sais-je. Paris: Presses Universitaires de France 1.ed., 2005.

MOIRAND, Sophie. De la médiation à la médiatisation des faits scientifiques et techniques: où en est l'analyse du discours? colloque Sciences, Médias et Société, 15-17 juin 2004, Lyon, ENS-LSH, Disponível em : <http://sciences-medias.ens-lsh.fr/ article.php3 ?id_article=59.> Acesso em: 17 set 2006.

PÊCHEUX, Michel. O discurso: estrutura ou acontecimento. Trad. de Eni Pulcinelli Orlandi. Campinas: Pontes, 1990. 